\title{
Chicken Paws By-products as an Alternative Source of Proteins
}

\section{PAVEL MOKREJS ${ }^{1 *}$, ROBERT GAL ${ }^{2}$, DAGMAR JANAEOVA ${ }^{3}$, MÁRIA PLAKOVA $^{2}$ and MICHAELA ZACHAROVA²}

${ }^{1}$ Tomas Bata University, Faculty of Technology, Department of Polymeric Engineering, Vavreekova 275, 76001 Zlín, The Czech Republic.

${ }^{2}$ Tomas Bata University, Faculty of Technology, Department of Food Technology, Rumy 4046, 76001 Zlín, The Czech Republic.

${ }^{3}$ Tomas Bata University, Faculty of Applied Informatics, Department of Processing Control and Applied Computer Science, NadStranimi 4511, 76005 Zlin, The Czech Republic

* Corresponding author. E-mail: mokrejs@ft.utb.cz

http://dx.doi.org/10.13005/ojc/330508

(Received: April 13, 2017; Accepted: June 10 , 2017)

\section{ABSTRACT}

The feet of chickens constitute a highly interesting, solid by-product of poultry processing methods. Although they contain a high proportion of proteins (mainly collagen) that could be utilized in various spheres of involvement, this is not happening at an adequate level presently. The problem lies in the presence of fat and other accompanying substances. The intention of this paper is to propose a means for processing chicken feet into protein isolate and, subsequently, for biotechnologically processing the protein isolate into collagen hydrolysate. The aforementioned accompanying substances were removed by adding the (milled) feet into $0.10 \%$ solution of $\mathrm{NaOH}$. The fat was removed by extraction of ethanol / petroleum ether (1:1). The protein isolate was processed hydrolytically with the aid of a food proteolytic enzyme into collagen hydrolysate. The collagen hydrolysate thus obtained was light in colour, exhibited excellent water-solubility and was easy to digest.

Keywords: Chicken paws, Proteins, Defatting process, Protein isolate, Enzyme hydrolysis, Collagen hydrolysate.

\section{INTRODUCTION}

Alongside an increase in the consumption of poultry, e.g. approximately $25 \mathrm{~kg}$ a year per inhabitant of the Czech Republic, there is a concurrent rise in the production of by-products from the slaughter of poultry, including feathers, blood, bones, skin, entrails, offal, glands, limbs and various adipose tissues. In fact, these by-products present potential risks to human health and the environment, so need to be eliminated either through disposing of them safely or finding alternative applications while maintaining strict hygiene standards. Indeed, slaughter houses for poultry would no doubt welcome any possibility for utilizing such by-products, which could lessen the 
financial burden involved in disposing of the same at institutes for veterinary sanitation or landfill sites; the latter is associated with the potential release of undesirable odours and groundwater contamination'.

It is worthy of note that certain secondary products from slaughtering practices are already treated for use or directly applied in various industrial sectors. The blood of waterfowl (ducks, geese) is an ingredient employed in food production. The blood of domesticated fowl (chickens, turkeys) features in the production of feed. Moreover, the skin and bones go into making gelatine, fertilizers and animal feed, while the fats contribute to creating soap, bio-fuels and lubricants, or act as a component in cosmetic products. The feathers can be hydrolysed into keratin hydrolysates and repurposed as a growth stimulator or feed additive, or find adoption in cosmetic applications ${ }^{2-7}$. In order to produce collagen hydrolysate, any tissue rich in collagen will suffice; e.g. skin, bones and tendons. Hydrolysates are components in dietary supplements, constitute functional ingredients in cosmetic formulations, and have found application in the medical sphere ${ }^{8}$. Moreover, such organic waste could be treated to facilitate energy conversion. For instance, carrying out anaerobic digestion transforms the waste into methane, after which the residual digestate may be used as a fertilizer in agriculture ${ }^{9,10}$. Another possibility is to compost the secondary protein products (containing excess $\mathrm{N}$ ), requiring them to be mixed with a suitable vegetable substrate (with excess $\mathrm{C}$ ) so as to optimize the ratio of $\mathrm{C}: \mathrm{N}^{11}$. Furthermore, certain types of waste (bone meal or keratin waste from poultry slaughterhouses) possess a considerable calorific value; hence incineration represents a potential means of harnessing this property. Note that other by-products from poultry slaughter (feet, heads, entrails and offal) need to be dried before efficient incineration can take place ${ }^{12}$.

According to EC directive No. 1774/2002, animal by-products are split up into 3 categories. Category 3 includes any parts of slaughtered animals that are suitable for consumption by humans (e.g. chicken heads, hides, skin, pelt, limbs, claw parts, wrist and metacarpal bones) ${ }^{13,14}$. Interestingly, chicken feet make up about 5\% of the weight of slaughtered poultry. The cuisine of some countries allows for their consumption after culinary preparation, although a large proportion is still thrown away. As chicken feet contain a high quantity of protein (mainly collagen), the option exists to transform them into products with greater added value, e.g. gelatine or hydrolysates, as might find application in pharmaceuticals, medicine, cosmetics or the food industry ${ }^{15}$. The literature contains reference to preparing gelatine (type A) through acidic processing of the skin and tendons of chicken feet, though poor yields of gelatine resulted ${ }^{16}$. The alkaline method for converting chicken feet into gelatine (type B) is not detailed in the literature, despite having been applied in the past for chicken and turkey heads ${ }^{17}$. Moreover, the manner for turning chicken feet into gelatine and hydrolysates by proteases is absent from the literature, in spite of offering numerous benefits (mild reaction conditions, and crucially neutral $\mathrm{pH}$ and low temperature). In the workplaces of the University, researchers have previously studied the enzymatic treatment of some solid by-products from animal slaughter processes, notably skin, tendons, poultry feathers and sheep wool. Of these, tendons have the capacity to be turned into high-quality gelatine, while deeper hydrolysis yields both collagen and elastin hydrolysates ${ }^{18,19}$. Keratin hydrolysate from feathers or wool can be constituted through means such as combined alkaline-enzymatic hydrolysis ${ }^{20-23}$, which is precisely why the authors consider the biotechnological conversion of chicken feet into protein products holds such promise.

\section{Objectives of the paper}

The aim of this paper is to propose a convenient means for processing chicken feet into a protein product (hydrolysate). Partial objectives comprise the following: a) purifying the raw material (removing fat and any accompanying noncollagenous proteins) and preparing the protein isolate; $b$ ) converting the protein isolate into collagen hydrolysate.

\section{MATERIAL AND METHODS}

The chicken feet were supplied by RACIOLA Uherský Brod, Lmt. Composition: dry matter $=35.0 \pm 3.0 \%$; constituted within the dry matter : total protein content $=48.3 \pm 0.4 \%$ (proportion of 
collagen $=82.8 \pm 0.7 \%$ ), fat content $=34.8 \pm 0.8 \%$, ash content $=16.1 \pm 0.2 \%$. The value for ash was determined gravimetrically after incinerating and annealing the sample ${ }^{24}$, the presence of fat was determined by Soxhlet extraction ${ }^{25}$, nitrogen was determined via the Kjeldahl method ${ }^{26}$, and the entire content of protein was established from the amount of nitrogen multiplied by 6.25 . The value for the collagen present was calculated from the amount of hydroxyproline (determined by colorimetry after hydrolysing the sample in $6 \mathrm{~mol} / \mathrm{LHCl}$ ) that was multiplied by a factor of $8^{27,28}$.

Protamex - a powder protease of the Bacillus family intended for the hydrolysis of food proteins. Constituents: ethanol, petroleum ether, $\mathrm{NaOH}$ (p.a.), 36-\% $\mathrm{HCl}$ (p.a.).

Equipment utilized: Meat mincer - SPAR Mixer SP-100AD-B; Nabertherm muffle furnace; WTW pH 526 pH meter; Kavalier LT2 shaker; Kern 770 analytical balance; Kern 440-47 laboratory weighing scales; oven - MEMMERT ULP 400; drying oven - WTB Binder E-28-TB1; hot plate magnetic stirrer - IKA LABORTECHNIK RCT BASIC; stainless steel sieve $1.0 \mathrm{~mm}$; Sevens-LFRA analyser for determining the solidity of gels.

As previously mentioned, prior to processing chicken feet into protein (collagen) hydrolysate, it is necessary to remove fat and other accompanying substances (non-collagenous proteins and pigments). Even though affordable lipolytic enzymes can be purchased, their efficiency on chicken feet was determined as insufficient (about $75 \%$ ). Additionally, reducing the fat present with $0.15 \mathrm{~mol} / \mathrm{L} \mathrm{NaHCO}_{3}$ proved inadequate, as had been used by the authors Du et al. to extract gelatine from chicken and turkey heads. Its efficiency for fat removal was observed to reach $80-85 \% 29$. Therefore, the approach taken herein was to remove fat from the chicken feet by extraction with solvent mixture.

The decision was taken to create the collagen hydrolysate from the protein isolate via a biotechnological method the University had utilized previously, which is outlined here. When preparing hydrolysates, enzymes sourced from Novozymes (Denmark) had proven effective. Out of these,
Protamex was selected as the most suitable option, as it adheres to purity requirements for food enzymes and is soluble in water. Other benefits include mild reaction conditions, i.e. $\mathrm{pH}$ 5.5-7.8 at temperatures of $35-60{ }^{\circ} \mathrm{C}$. The literature refers to Protamex in the context of processing by-products from fish ${ }^{30,}{ }^{31}$. When formulating the collagen hydrolysates, a method analogous to the production of gelatine was followed. The protein isolate first underwent treatment adhering to the enzyme methodology, after which it was extracted with hot water at elevated temperature in order to obtain a water-soluble protein (hydrolysate) in solution form. Studying the influence exerted by certain parameters in the preparation of collagen hydrolysate involved carrying out two-level factorial experiments, in which three factors were monitored; as performed for one central experiment and one repetition. The specifications of the various factors and their levels are detailed as follows. Factor A - adding the enzyme: minimum value = $1 \%$ (in accordance with the dry weight of the processed material, w/w), mean value $3 \%(w / w)$, maximum value $5 \%(\mathrm{w} / \mathrm{w})$; factor $\mathrm{B}$ - temperature for extraction: minimum value $60{ }^{\circ} \mathrm{C}$, mean value $75^{\circ} \mathrm{C}$, maximum value $90^{\circ} \mathrm{C}$; factor $\mathrm{C}$ - duration of extraction: minimum 2 hours, mean duration 5 hours, maximum 8 hours. Arranging the experiments in this way enabled subsequent statistical evaluation, pertaining to the impact of said monitored factors on the degree of conversion (expressed as the percentage of conversion of the original substrate into collagen hydrolysate).

Figure.1 comprises a block diagram illustrating how collagen hydrolysates were derived from chicken feet. The means for preparing collagen hydrolysate is described below in seven steps:

The chicken feet sourced from the poultry slaughtering facility were initially washed in cold water to remove any remaining blood and dirt. Then they were ground in the meat mincer into pieces 6 $\mathrm{mm}$ in size.

Removing the non-collagenous proteins and pigments involved mixing the raw material with $0.10 \% \mathrm{NaOH}$ solution at the ratio $1: 8(\mathrm{w} / \mathrm{v})$, and shaking it for $45 \mathrm{~min}$. at room temperature. The resulting matter was then filtered through a stainless 
steel mesh sheet and washed with water; these actions were repeated three times.

The material obtained was spread out on a metal sheet and left to dry for $48 \mathrm{~h}$. in a drier with air circulating at the temperature of $35^{\circ} \mathrm{C}$.

This step comprised defatting the raw material by cold extraction by ethanol and petroleum ether combined at the ratio 1:1. During the defatting process, the raw material was mixed with the solvent mixture at the ratio of $1: 6(\mathrm{w} / \mathrm{v})$ and shaken at room temperature for $34 \mathrm{~h}$. The solvent was replaced with a fresh dose after 6,12 and 24 h, with filtration through a stainless steel mesh sheet. The defatted raw material was spread out and left in a fume hood for about $1 \mathrm{~h}$, permitting any residual solvent to evaporate. Thus, the protein isolate was prepared, which could be stored at room temperature.

The protein isolate was mixed with water at the ratio $1: 8(\mathrm{w} / \mathrm{v})$, and then enzymatically treated in a mildly acidic environment $(\mathrm{pH} 6.0 \pm 0.3)$ while being shaken for $46 \mathrm{~h}$. at room temperature. The following additions of the enzyme (factor A) were tested: $1 \%, 3 \%$ and $5 \%$; addition of the the enzyme was carried out relative to the dry weight of the processed material.

Once the enzymatic treatment was over, the system was heated to the temperature pertaining to factor $\mathrm{B}\left(60^{\circ} \mathrm{C}, 75^{\circ} \mathrm{C}\right.$ or $\left.90^{\circ} \mathrm{C}\right)$. Upon reaching the prescribed temperature, the collagen hydrolysate was extracted for the duration of time determined by factor $\mathrm{C}(2,6$ or $8 \mathrm{~h}$.); during extraction, the mixture was stirred with a magnetic stirrer.

On completion of step 6 , the system was filtered through a stainless steel mesh sheet fitted with 3 layers of PAD fabric (pore size $300 \mu \mathrm{m}$ ). The solution of collagen hydrolysate thus prepared can either be thickened or dried. Herein, the hydrolysate was dried into a thin film in a drier at the temperature of $50 \pm 0.5^{\circ} \mathrm{C}$ for 48 hours. The solid residue was dried at $103 \pm 1.0^{\circ} \mathrm{C}$ for $24 \mathrm{~h}$; its weight was subsequently included in the calculation for mass balance.

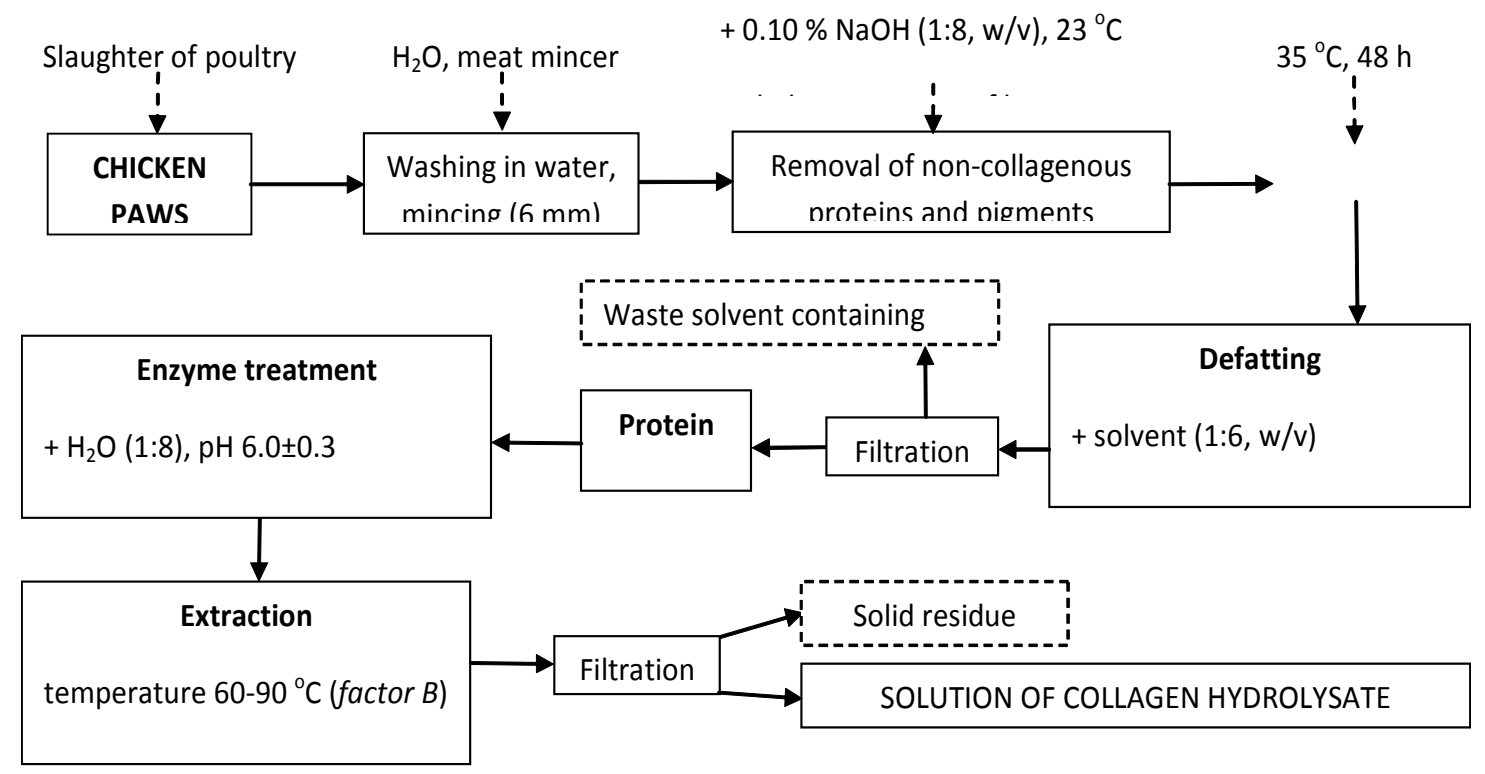

Fig. 1. Block diagram of processing chicken paws into collagen hydrolysate

\section{RESULTS AND DISCUSSION}

Table 1 summarizes findings from transforming the protein isolate into collagen hydrolysate, comprising two-level factorial experiments with 3 monitored factors. The degree of conversion was calculated from the amount of prepared hydrolysate relative to the initial weight of the protein isolate according to Formula (1). Balance error is expressed as the difference in per cent 
between the input (the protein isolate) and outputs (collagen hydrolysate + solid residue), see Formula (2). The content of ash in the collagen hydrolysate was determined gravimetrically after incinerating and annealing the sample ${ }^{24}$.

$\eta \quad$ degree of conversion (\%)

$\mathrm{m}_{1} \quad$ weight of collagen hydrolysate, dry matter $(\mathrm{g})$

$\mathrm{m}_{0} \quad$ weight of protein isolate, dry matter $(\mathrm{g})$

MBE mass balance error (\%)

$\mathrm{m}_{1} \quad$ weight of collagen hydrolysate, dry matter $(\mathrm{g})$

$\mathrm{m}_{2} \quad$ weight of solid residue, dry matter $(\mathrm{g})$

$\mathrm{m}_{0} \quad$ weight of protein isolate, dry matter $(\mathrm{g})$

The results stemming from the extent of

conversion and content of ash in the hydrolysates statistically significant factor A (addition of the enzyme). Regression equations possess the following form:

$\eta=66.81+0.5250 A-0.2561 B+0.7833 C+$ $0.01500 A B-0.2000 A C-0.004861 B C+0.002083$ $\mathrm{ABC}$

$\mathrm{ASH}=-8.125+3.158 \mathrm{~A}+0.1336 \mathrm{~B}+1.450 \mathrm{C}-$ $0.02250 A B-0.2667 A C-0.01514 B C+0 ., 002917$ $\mathrm{ABC}$

$A, B, C$ factors monitored during processing $A B, A C$, $B C, A B C$ interacting groups

In order to illustrate the influence of the technological factors monitored on conversion of the protein isolate into collagen hydrolysate, the values for extent of conversion and content of ash

Table 1: Breakdown of factorial experiments and results from transforming the protein isolate into collagen hydrolysate

\begin{tabular}{|c|c|c|c|c|c|c|}
\hline \multirow[t]{2}{*}{ Run } & \multicolumn{3}{|c|}{ Factors under study } & \multirow{2}{*}{$\begin{array}{c}\text { Degree of } \\
\text { conversion } \\
(\%)\end{array}$} & \multirow{2}{*}{$\begin{array}{c}\text { Mass } \\
\text { balance } \\
\text { error } \\
(\%)\end{array}$} & \multirow{2}{*}{$\begin{array}{c}\text { Ash } \\
\text { content in } \\
\text { hydrolysate } \\
\text { * }(\%)\end{array}$} \\
\hline & $\begin{array}{c}\text { A } \\
\text { Enzyme } \\
\text { addition(\%) }\end{array}$ & $\begin{array}{c}\text { B } \\
\text { Extraction } \\
\text { temperature }\left({ }^{\circ} \mathrm{C}\right)\end{array}$ & $\begin{array}{c}\text { C } \\
\text { Extraction } \\
\text { time(h) }\end{array}$ & & & \\
\hline 1 & 1 & 60 & 2 & 53.7 & 4.6 & 2.6 \\
\hline 2 & 1 & 60 & 8 & 56.2 & 4.1 & 5.3 \\
\hline 3 & 1 & 90 & 2 & 46.3 & 4.9 & 5.2 \\
\hline 4 & 1 & 90 & 8 & 48.3 & 4.8 & 5.7 \\
\hline 5 & 5 & 60 & 2 & 58.8 & 0.3 & 9.1 \\
\hline 6 & 5 & 60 & 8 & 59.3 & 0.3 & 9.6 \\
\hline 7 & 5 & 90 & 2 & 53.7 & 0.4 & 9.7 \\
\hline 8 & 5 & 90 & 8 & 55.4 & 2.7 & 10.1 \\
\hline 9 & 3 & 70 & 5 & 59.3 & 4.4 & 8.2 \\
\hline
\end{tabular}

* based on dry matter

$\eta=\frac{m_{1}}{m_{0}} 100$

were analysed in statistical software Minitab® 17.2.1 (Fujitsu, Japan). The statistical significance of the monitored factors within the limits observed was evaluated by the standard technique

$$
M B E=\frac{\left|\left(m_{1}+m_{2}\right)-m_{0}\right|}{m_{0}} 100
$$

of Fisher's exact test for significance and P-values for the degree of reliability of $95 \%{ }^{32}$. For the extent of conversion, $(\eta)$ constitutes the statistically significant factors $A$ (addition of the enzyme) and $B$ (temperature of extraction). For the content of ash in the hydrolysates, (ASH) constitutes the in the hydrolysates were plotted as interaction and contour graphs; the latter contour graphs present the impact of two major factors on the monitored variable.

Figure. 2 shows the effect of interactions between the monitored factors; it also contains a contour graph demonstrating the impact of enzyme addition and extraction temperature on the extent of conversion. In terms of enzyme and temperature interaction, at a constant temperature, the extent of conversion rises in parallel with greater addition of the enzyme. At the lowest extraction temperature $\left(60{ }^{\circ} \mathrm{C}\right)$, a greater level of conversion takes place than at the uppermost extraction temperature $(90$ $\left.{ }^{\circ} \mathrm{C}\right)$. However, the highest degree of conversion is observed under the conditions of the central experiment $\left(3 \%\right.$ enzyme, $\left.75^{\circ} \mathrm{C}\right)$. In relation to 
interaction between enzyme and duration, it is obvious that further addition of $t$ within the limits set ( 2 and 8 h.) exhibits no significant effect on the level of conversion. In fact, conversion was at its highest under the conditions of the central experiment (3\% enzyme, 5 hours). The interaction of temperature and time shows that conversion diminishes concurrently with rise in temperature of extraction. Note that the duration of extraction within the limits set $(2$ and 8 h.) exerts no significant impact on the degree of conversion, the latter peaking under the conditions of the central experiment $\left(75^{\circ} \mathrm{C}, 5\right.$ hours $)$. The contour graphs clearly present the findings of the interaction graphs discussed herein. Limited conversion $(<50 \%)$ is achieved with a low dose of enzyme $(<1.5 \%)$ at a high extraction temperature (just exceeding $83^{\circ} \mathrm{C}$ ). Notice how the extent of conversion goes up at lower extraction temperatures alongside concurrent increase in enzyme addition.

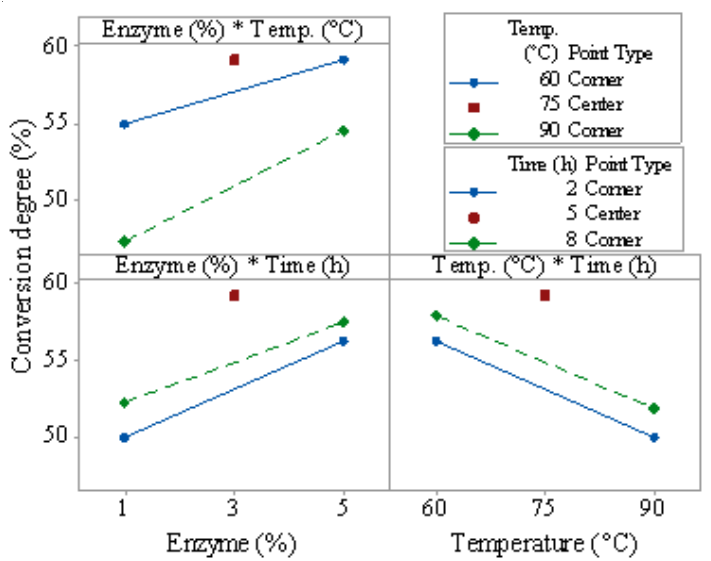

Conversion either reaches its peak (58-59\%) under conditions approximately equivalent to the central experiment (temperature $70-77^{\circ} \mathrm{C}$ and $2.6-3.6 \%$ enzyme), or under conditions approaching the uppermost point of enzyme addition ( $>4.5 \%$ ) and the lower limit of extraction temperature $\left(<63^{\circ} \mathrm{C}\right)$.

Figure. 3 displays the effect of interaction by the monitored factors, while the contour graph illustrates how enzyme addition and extraction temperature impact the content of ash in the hydrolysates. Analysing interaction between the factors of enzyme and temperature reveals that, at constant temperature, the content of ash rises as enzyme addition is increased. At the lowest extraction temperature $\left(60^{\circ} \mathrm{C}\right)$, a slightly lesser presence of ash is seen than at the uppermost extraction temperature $\left(90^{\circ} \mathrm{C}\right)$. In fact, the least amount of ash was recorded under conditions of

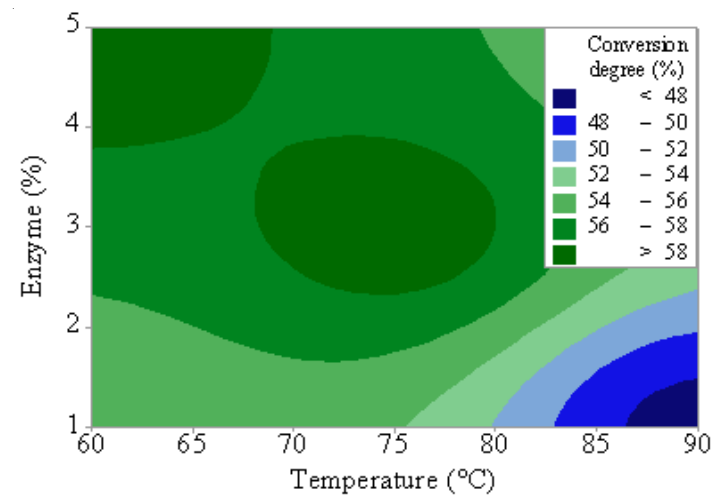

Fig. 2. Graph on interaction between the monitored factors (left); contour graph on the influence of enzyme addition and extraction temperature (right) on the degree of conversion

minimal enzyme addition (1\%) at the extraction temperature of $60^{\circ} \mathrm{C}$. In terms of interaction between the factors of enzyme and duration, a similar circumstance occurs; i.e. with duration of extraction at a constant, ash content and enzyme addition rise in parallel with each other; the least presence of ash was witnessed under conditions when enzyme addition (1\%) and extraction time (2 h.) were both at a minimum. Interaction between temperature and duration is such that once $2 \mathrm{~h}$. of extraction has passed, ash gains in content as extraction temperature rises. Conversely, subsequent to 8 hours of extraction, a subtle rise in ash content occurs in conjunction with increase in temperature. The least presence of ash is reported under conditions of the lowest extraction temperature $\left(60^{\circ} \mathrm{C}\right)$ and shortest extraction time (2 hours).

\section{CONCLUSION}

Waste chicken feet were processed in 2 technological phases. Initially, all accompanying substances and fats were removed, as this is key to obtaining proteins from chicken feet and any future utilization. The highest efficiency of fat removal was achieved through extraction with a solvent mixture of ethanol and petroleum ether (ratio 1:1, v/v). Upon 34 hours of extraction at room temperature with 4 shaking cycles, it was possible to prepare a protein isolate exhibiting a high content of protein (up to $95 \%)$. A product prepared in this manner would 

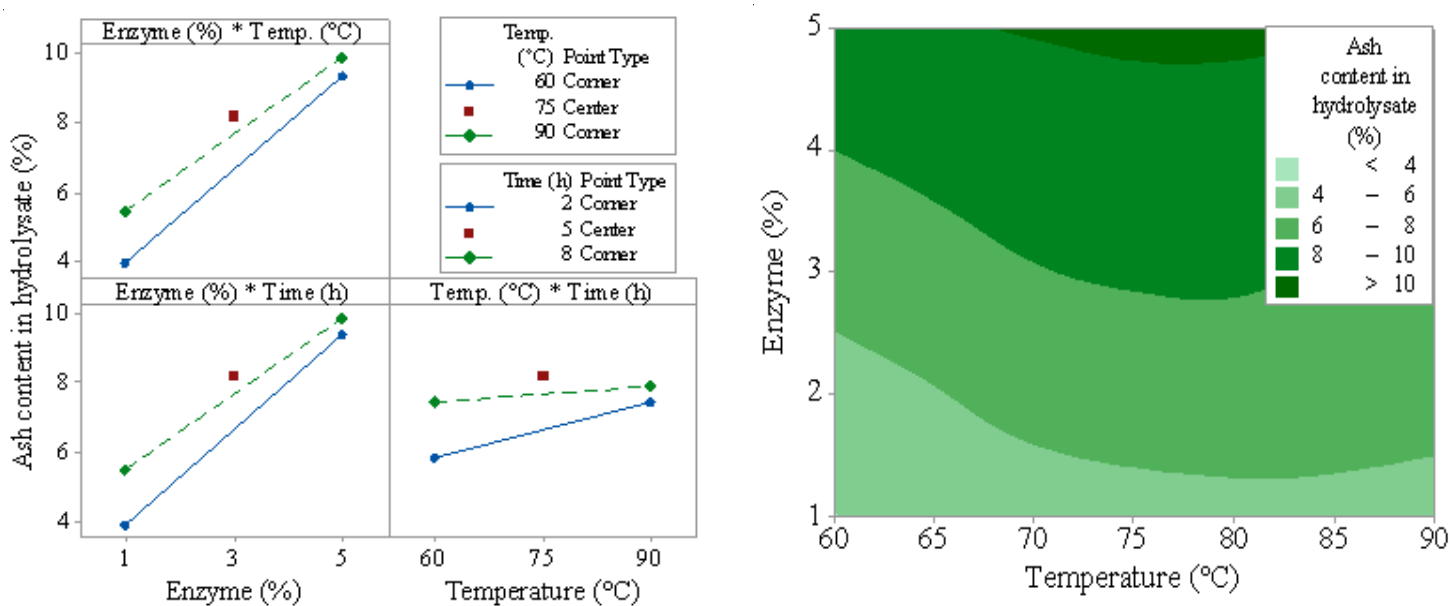

Fig. 3. Graph on interaction between the monitored factors (left); contour graph on the influence of enzyme addition and extraction temperature (right) on ash content in the hydrolysates

boast long-term stability and could be used in that very form (e.g. as an additive in animal feed or in the food industry) or undergo further processing. The second phase involved converting the prepared protein isolate by applying a proteolytic enzyme. Selected parameters of hydrolyses were monitored (enzyme addition, extraction temperature, duration of extraction), and the impact of the same on the degree of conversion was observed (expressed as transformation of the protein isolate into collagen hydrolysate, in per cent). Following statistical evaluation of the results, optimal conditions were proposed for conversion of the protein isolate into collagen hydrolysate. In brief, the protein isolate was mixed with water at the ratio of $1: 8,3 \%(\mathrm{w} / \mathrm{w})$ protease Protamex was added, and the mixture was shaken for $46 \mathrm{~h}$. at $\mathrm{pH}$ 6.0 at room temperature. Subsequently, $5 \mathrm{~h}$. of extraction took place at $75^{\circ} \mathrm{C}$, and the collagen hydrolysate was separated by filtration; the degree of conversion equalled approximately $60 \%$.
Collagen hydrolysate is highly soluble in water and easy to digest, so has the potential to be used as a dietary supplement, an additive in the food industry or a component in animal feed, or could be suitably prepared for cosmetic purposes. The technology presented herein for processing chicken feet into protein isolate and collagen hydrolysate is straightfoward, as only mild reaction conditions are required under atmospheric pressure. Indeed, it represents an interesting means for poultry processors to utilize solid protein by-products that are considered waste presently. As a footnote, the University is currently developing technology to convert chicken feet into gelatine, as part of its research into comprehensively processing byproducts arising through the slaughter of poultry.

\section{ACKNOWLEDGMENTS}

This article was written with support of the projectS IGA/FT/2017/007andlGA/FT/2017/004

\section{REFERENCES}

1. Ockerman, H. W., Hansen, C. I.: Animal ByProduct: Processing \& Utilization. Woodhead Publishing, London., 2000.

2. Pitk, P., Kaparaju, P., Vilu, R.: Bioresour. Technol., 2012. 116, 42.

3. Schrieber, R., Gareis H.: Gelatine Handbook: Theory and Industrial Practice. Wiley-VCH,
Weinheim., 2007.

4. Secchi, G.: Clin. Dermatol., 2008. 26, 321.

5. Flick, E. W. Cosmetic and toiletry formulations. Noyes Publications, New Jersey 1996.

6. Conca, K. R., Yang, T. C. S.: Edible food barrier coatings. In: Biodegradable Polymers 
and Packaging (Ch. Ching, D. Kaplan, E.L. Thomas). Technomic Publishing, Lancaster., 1993.

7. Coutand, M., Cyr, M., Deydier, E., Guilet, R., Clastres, P.: J. Hazard. Mater., 2008, 150, 522.

8. Dybka, K., Walczak, P.: Food Chem. Biotechnol., 2009, 73, 83.

9. Khalid, A., Arshad, M., Anjum, M., Mahmood, T., Dawson, L.: Waste Manage., 2011, 31, 1737.

10. Alvarez, R., Lidén, G.: Renewable Energy., 2008, 33, 726.

11. Barrena, R., Artola, A., Vázquez, F., Sánchez A.: J. Hazard. Mater., 2009, 161, 380.

12. Cliffe, K. R., Patumsawad, S.: Waste Manage., 2001, 21, 49.

13. Regulation (EC) No. $1774 / 2002$ of the European Parliament and of the Council laying down health rules concerning animal by-products not intended for human consumption.

14. Lawrie, R. A., Ledward, D. A.: Lawrie's Meat Science. Woodhead Publishing, Boca Raton 2006.

15. Lasekan A., Abu Bakar F., Hashim D.: Waste Manage., 2013 33, 552.

16. Almeida, P. F., Da Silva Lannes, S. C.: J. Food Process. Eng., 2013 36, 824.

17. Xu, M., Wei, L., Xiao, Y., Bi, H., Yang, H., Du, Y.: Int. J. Biol. Macromol., 2017, 95, 1246.

18. Mokrejs, P., Janacova, D., Svoboda, P.: Appl. Biochem. Biotechnol., 2012,168, 917.

19. Mokrejs, P., Janacova, D., Svoboda, P., Cermak, R.: Res. J. Chem. Environ., 2014, 18, 52.
20. Mokrejs, P., Krejci, O., Svoboda, P., Vasek, V.: Rasayan J. Chem., 2011, 4, 728.

21. Mokrejs, P., Krejci, O., Svoboda, P.: Orient. J. Chem., 2011, 27, 1303.

22. Mokrejs, P., Svoboda, P., Hrncirik, J., Janacova, D., Vasek, V.: Waste Manage. Res., 2011, 29, 260.

23. Mokrejs, P., Hrncirik, J., Janacova, D., Svoboda, P.: Asian J. Chem., 2012, 24, 1489.

24. Davidek, J., Hrdlicka, J., Karvanek, M., Pokorny, J., Seifert, J., Velisek, J.: Handbook of Food Analysis. SNTL, Prague., 1985.

25. ISO 1443:1973, Meat and meat products Determination of total fat content.

26 ISO 937:1978, Meat and meat products Determination of nitrogen content.

27. ISO 3496:1994, Meat and meat products Determination of hydroxyproline content.

28 Vazques-Ortiz, F., Gonzales-Mendez, N. F.: J. Food Anal., 1996, 9, 269.

29. Du, L., Khiari, Z., Pietrasik, Z., Betti, M.: Poultry Sci., 2013, 92, 2463.

30. Nguyen, H. T. M., Sylla, K. S. B., Randriamahatody, Z., Donnay-Moreno, C., Moreau, J., Tran, L. T., Bergé, J. P.: Food Technol. Biotechnol., 2011, 49, 48.

31. Dumay, J., Allery, M., Donnay-Moreno, C., Barnathan, G., Jaouen, P., Carbonneau, M. E., Bergé, J. P.: J. Sci. Food Agric., 2009, 89, 1599.

32. Stange, K. Angewandte Statistik: Teil 2: Mehrdimensionale Probleme. Springer Verlag, Heidelberg., 1971. 